\title{
Developing Direction Exploration of Modern Rural Tourism Industry
}

\author{
Zhao Ying \\ Tourism and civil aviation management institute, Haikou College of Economics, Haikou, 571127, \\ China
}

Keywords: Rural tourism; Industry; Development direction

\begin{abstract}
The development of modern rural tourism industry is not independent. To realize the development, we should pay attention to the relationship between tourism and agriculture. It can promote the internal and external construction symbiosis model through the application of resources. Through strengthening the co-operation of rural tourism industry entities, combine modern rural tourism resources organically in order to form a cluster effect and improve the competitiveness of modern rural tourism industry. This article discusses the development direction of rural tourism industry under modern environment.
\end{abstract}

The development of rural tourism not only promotes the rapid and healthy development of rural economy, but also enriches the daily life of rural people, while the development of rural tourism industry also promotes the upgrading and optimization of rural industrial structure. China's tourism industry flourishes. Rural tourism with rural pastoral landscape characteristics has become a new tourist hot spot, and rural tourism industry has been expanding. Although China's rural tourism has a better development opportunity, in the development there are a series of problems. These problems constrain the further development of rural tourism industry. In this case, it has a strong practical significance to explore the development trend of modern rural tourism industry and development path.

\section{Problems in the development of China's modern rural tourism industry}

A. The financing capacity of rural tourism needs to be improved

At present, China's rural tourism development is relatively large. Despite the formation of a certain scale, the actual operations of rural tourism projects are less, and lack brand characteristics, which led to poor financing and gold suction capacity of rural tourism industry. Modern rural tourism services are relatively simple with serious homogeneous. For example, the "farmhouse" rural tourism project development is mostly in the direct provision of accommodation or local attractions visit, ignoring the business opportunities characteristics of agricultural products and folk goods. Rural resources has little excavation efforts in folk customs, folk participation and other aspects. The development of tourism products lack innovative design and cultural taste, so it is difficult to show the value of rural tourism investment. This will affect the attractiveness rural tourism products and the return rate of tourists.

In the development of rural tourism industry, these factors will have a greater negative impact on the sustainable development of the industry, and will directly reduce the profit margins of the industry, resulting in lack of development potential. The adverse development of rural tourism industry will also affect the modern credit needs.

$B$. The development of rural tourism industry is relatively weak

China's rural tourism industry can be said to have developed from the past ten years. Compared to historical and cultural tourism resources, the development of rural resources is relatively thin. This weak is mainly in two aspects: First, the cooperation of rural tourism and agricultural resources is weak in the process of rural tourism industrialization. We should not only pay attention to the development of natural landscape and other resources, but also attach importance to the development of agricultural resources. Agriculture and tourism can be combined organically to provide resources for the development of rural tourism industry. Generally speaking, the local agricultural ecological resources in rural tourism industry development are good, such as in Wuyuan 
County's rural tourism industry development. The local agricultural ecological resources, cultural resources, property brand resources are relatively rich, compared to the surrounding areas, and its tourism development advantages are more significant, but in actual industrial development and planning, lack of development awareness results in a lot of agricultural ecological resources cannot be fully utilized, and it cannot form a more mature rural tourism development system. Second, modern rural tourism product development system is immature. At present, China's modern rural tourist attractions show features like a large number, small scale, and scattered distribution. From the overall view, the rural tourism development supporting resources is far from place, such as quality of service, traffic quality, environmental quality and the quality of agricultural products. Rural tourism product development system is not mature, and it is difficult to comprehensively improve the industry construction level.

\section{China's modern rural tourism industry development direction}

\section{A. The local government-led intensity is significantly increased}

China's modern rural tourism industry shows government-oriented trend in the development, mainly because the local government pays more attention to rural tourism, and it supports the development of modern rural tourism through technology, capital and policies. In the process of industrial development, it pays attention to industry construction, and promotes it as the overall plan of tourism industry development. In recent years, the local government gives growing concern about the development of rural tourism industry. It fully supports and nurtures rural economic development as a new growth point of the tourism industry. Through the official website, meet the rural tourism development planning publicity, introduce some professional policy, and develop modern rural tourism industry.

\section{B. Rural tourism industry develops toward experience direction development}

With the development of modern tourism industry and the change of tourists' motives, the modern rural tourism gradually changes from simple aesthetic sightseeing into leisure, comfort and aesthetics, which emphasizes the experience of rural tourism. The change of rural tourism form leads to a big change in modern rural tourism industry. In industrial construction, pay attention to improve the experience of rural tourism and service, improve the degree of tourists' experience to achieve the function of tourism services. In addition, the experience of modern tourism industry also embodies concerns about the activities related to rural tourism, such as the local rural tourism industry development planning. Considering the local traffic, basic necessities and other implementation possibilities, visitors may experience the charm of rural tourism through the show of local rural tourism traffic environment and natural living environment in order to increase the amount of tourists and comprehensively improve the scale of rural tourism industry development.

\section{Investment diversification}

Modern rural tourism industry investment subjects are of diversification. With the fast development trend of modern rural tourism industry, China's modern rural tourism industry gradually changes from self-management to collective management. Such as in rural tourism development, it is mainly farmers operations independently. This rural tourism has characteristics, including little investment, small scale, and slow development. With the improvement of our economy, people's spiritual and cultural ideas continue to innovate. Rural tourism has gradually been developed and utilized, and rural tourism has become the new economic growth point of modern countryside. Rural tourism has become modern countryside's new economic growth point. One of the performances of rural tourism is that it changes from single individual business into a partnership and village collective investment and management. Capital comes not only from domestic powerful companies and groups, but also there is the emergence of urban capital.

D. Rural tourism industry' s characteristics, scale, and brand are to be strengthened

China's modern rural tourism industry attaches importance to the characteristics, size and brand building, and improves from construction concept and construction situation. In the development of modern rural tourism industry, due to the increasing pressure of market competition, it has become 
a necessary way to develop modern rural tourism enterprises. Therefore, in actual construction, it is necessary to change development concept, carry on innovative design and improve industrial development competitiveness, strengthen rural tourism industry characteristics, scale, brand building, and comprehensively improve market share.

\section{E. Diversification of rural tourism industry types}

China's modern rural tourism types continue to increase. The development gradually shows better economic, social and ecological effects. In order to achieve sustainable development, China's modern rural tourism industry must continue to develop, optimize rural industrial structure, and promote modern rural tourism industry structure changes. Modern rural tourism industry structure shows a diversified trend, such as agricultural products, handicrafts, folk goods and other production get better development in the development of rural tourism. These elements fuse into rural tourism industry to meet the modern rural tourism industry’s diversification needs.

\section{China's modern rural tourism industry development strategy}

\section{A. Ecological priorities combine with moderate development}

Modern rural tourism industry must adhere to the principles of ecological priority and moderate development in the development process to achieve ecological benefits and economic benefits and achieve modern rural tourism industry's healthy and sustainable development. The development of modern rural tourism industry is based on tourism resources. In this process, the natural resources of rural tourism and the quality of rural environment will affect the quality of industrial development. Therefore, in the development of rural tourism industry, we should play ecological benefits, carry out reasonable and appropriate development according to environment load ability, and avoid ecological damage. Modern rural tourism industry construction should adhere to the principles of humanities with reasonable control of the amount of tourists in spots. The development of tourists should also consider food and shelter, etc. to allow visitors to get the best life experience, and in the meantime, the tourism enterprises can get the best economic benefits.

B. Characteristic tourism combines with publicity and education

In order to improve the market competitiveness, modern rural tourism industry must attach importance to the development of special tourism resources. Not only develop natural resources, so that visitors can watch the natural scenery, but also attach importance to the development of rural tourists' connotation, so that tourists can better understand nature and have emotional cultivation.

Also rural tourism industry development cannot be separated from publicity and education. In actual publicity, enterprises should strengthen ties with the government, make reliable propaganda strategy based on the understanding of the village characteristics and promote real rural tourism.

Therefore, in the development of modern rural tourism industry, we should attach importance to environmental education, scientific civilization propaganda, strengthen publicity and education, and promote rural tourism human resources and natural environment together. Through publicity and education, attract tourists' sight, enhance people's ecological environment awareness and legal concepts, and serve socialist harmonious society.

\section{Industrial chain optimization and improvement}

Rural tourism industry is essentially a symbiotic system. In the development, we must coordinate the symbiotic relationship in and out of the industry, construction and improvement of rural tourism industry chain. First of all, the development of local rural tourism industry should build a "leading", so that leading enterprises can fully promote the development of rural tourism industry, and promote a virtuous circle of the entire industry chain; Secondly, rural tourism industry should form industrial chain linkage, and organically unite every element in rural tourism, achieve co-prosperity and promote the spontaneous formation of industry linkage; Thirdly, in the development, rural tourism industry chain also needs to pay attention to the realization of rural tourism product variety and level of diversification, increase modern rural tourism industry investment, whether technology or funds to improve the overall infrastructure construction of industrial development level; Finally, modern rural tourism industry need to further improve the cultural connotation of tourism products and create tourism brand in order to achieve further 
development. The development of rural tourism industry needs to improve the cultural connotation of the tourism products and create cultural brands. Rural tourism products need to further develop from cultural connotation. Create cultural tourism products or handicrafts with unique geographical characteristics, form rural tourism brand products, and promote the optimization of product structure.

\section{Conclusion}

In the development process of China's modern tourism industry, we should overcome the obstacles to industrial development, increase rural tourism resources development efforts, and improve the financing capacity of modern rural tourism resources. Build rural tourism development model and highlight the characteristics of industry. In addition, we must attach importance to the construction of modern rural tourism resources brand, form a brand effect, and in the industrial development, strengthen publicity so that people can get better cultural resources in tourism resources; and in regional construction, strengthen tourism industry cooperation mechanism to improve tourism industry's market competitiveness through cooperation mechanism comprehensively, and achieve the sustainable development of modern rural tourism.

\section{References}

[1] Wen Jun, Li Xingqun. Research on the development and change of rural mini-tourism enterprises in minority areas ---- An empirical analysis based on Guangxi rural mini-tourism enterprises [J]. Guangxi National Studies, 2014, (1): 146-156.

[2] Cheng Zhe, Cai Jianming, Cui Li. Rural transformation development industry-driven mechanism: Taking Panjin rural tourism as an example [J]. Agricultural Modernization Research, 2016,37 (1): 143-150.

[3] Li Hongxian, Chu Deping. Ease village and enjoy pastoral: old-age rural tourism new opportunities ---- Based on the Integration of old-age tourism, rural tourism and eco-tourism [J]. Resource Development and Market, 2015,31(4):493-496.

[4] Dai Linlin. From city to countryside: festival development reason and application prospect of the rural area [J]. Journal of Geographical Research and Development, 2012,31 (6): 76-81,86.

[5] Li Yongjun, Wang Qingsheng. Rural culture and tourism industry integration development research [J]. Finance Theory and Practice, 2016,37 (3): 128-133.

[6] Fu Qiang. Study on the Development of Rural Vacation Tourism in Tongzi County [J]. Journal of Zunyi Normal University, 2015, (4): 43-47.

[7] Chen Lingling, Qiu Lin, Feng Nianhua. The characteristics and development model of tourism-oriented ecological villages under new urbanization [J]. Journal of Jiangsu Agricultural Sciences, 2016,44 (10): 520-523.

[8] Yu Haitao, Ma Bo, Chen Lei. Rural tourism return nature: rural cognition and protection [J]. China Population, Resources and Environment, 2012,22 (9): 158-162. 